


\title{
Features of the investigation of hooliganism committed by football fans
}

\author{
DOI: https://doi.org/10.46398/cuestpol.3969.32
}

\author{
Viktor Boiarov * \\ Mikhail Larkin ** \\ Oleh Kyrychenko *** \\ Sergey Penkov **** \\ Oleh Kruhlov *****
}

\begin{abstract}
The article is devoted to the analysis of some features of the investigation of football hooliganism. The current state and trends of football hooliganism are considered (including during the COVID-19 pandemic). The main problems faced by the investigation authorities during the detection and investigation of football hooliganism have been identified. In the process of working on the article, the scientific literature on informal youth groups, the fight against extremism, the investigation of group crimes of football fans was analyzed. The purpose of the study is to identify and study the features of the investigation of hooliganism committed by football fans. The object of research is the peculiarities of the investigation of hooliganism committed by football fans. During the writing of the article, the following methods were used: observation, analysis, synthesis, comparison, generalization, extrapolation, modeling, and information approach. As a result of the conducted research, the modern tendencies of football hooliganism are defined. Emphasis is placed on the peculiarities of the transformation of football fans. The principal problems of detection and investigation of football hooliganism are outlined, recommendations for prevention and counteraction to crimes committed by football fans are
\end{abstract} developed.

Keywords: football, football fans, hooliganism, investigations, methodical recommendations.

* Ph. D., Professor of Department of Criminal Procedure and Forensics of Academy of Advocacy of Ukraine. boyarvi2017@gmail.com. https://orcid.org/o000-0001-9155-505X

** Ph. D., Associate Professor of Department of Criminal Law and Justice of Zaporizhzhia National University.malark777@ukr.net. https://orcid.org/oooo-0002-4676-46oX

*** Doctor of Legal Sciences, Associate Professor, Rector Private Institution of higher education «Dnipro humanitarian university». kirichenkooleg75@ukr.net. https://orcid.org/oooo-0oo2-2046-9522

**** Doctor of Legal Sciences, Professor of Law Department of Private institution of higher education «Dnipro humanitarian university». psv930osvp@gmail.com. https://orcid.org/oooo-0003-40445824

***** Ph. D. in Law, Associate Professor of the Department of Law of Berdyansk State Pedagogical University. olegbrd79@gmail.com. https://orcid.org/oooo-0oo2-2266-1323. 


\section{4 \\ Viktor Boiarov, Mikhail Larkin, Oleh Kyrychenko, Sergey Penkov y Oleh Kruhlov \\ Features of the investigation of hooliganism committed by football fans \\ Características de la investigación del vandalismo cometido por aficionados al fútbol}

\section{Resumen}

El artículo está dedicado al análisis de algunas características de la investigación del vandalismo en el fútbol. Se consideran el estado actual y las tendencias del vandalismo en el fútbol (incluso durante la pandemia de COVID-19). Se han identificado los principales problemas a los que se enfrentan las autoridades investigadoras durantela detección einvestigación del vandalismo en el fútbol. En el proceso de elaboración del artículo se analizó la literatura científica sobre los grupos juveniles informales, la lucha contra el extremismo, la investigación de delitos colectivos de los aficionados al fútbol. El propósito del estudio es identificar y estudiar las características de la investigación del vandalismo cometido por los aficionados al fútbol. El objeto de investigación son las peculiaridades de la investigación del vandalismo cometido por los aficionados al fútbol. Durante la redacción del artículo se utilizaron los siguientes métodos: observación, análisis, síntesis, comparación, generalización, extrapolación, modelado y enfoque de la información. Como resultado de la investigación realizada, se definen las tendencias modernas del vandalismo en el fútbol. Se hace hincapié en las peculiaridades de la transformación de los aficionados al fútbol. Se describen los principales problemas de detección e investigación del vandalismo en el fútbol, se desarrollan recomendaciones para la prevención y contrarrestar los delitos cometidos por los aficionados al fútbol.

Palabras clave: fútbol, aficionadosalfútbol,vandalismo, investigaciones, recomendaciones metódicas.

\section{Introduction}

Sport is a special area of public relations (Kharytonov et al., 2021). This type of human activity has long been characterized by a set of virtues that required a great deal of effort, perseverance, adherence to high moral principles and ethical standards (Kolomoiets et al., 2021). Currently, the legal support for professional sports remains at a very low level (Tkalych et al., 2020). Considering the transformational changes in modern football, which is gradually becoming a larger business platform (Kolomoets et al., 2017), we can not ignore those, who consider themselves the most loyal fans of the "game of millions" - football fans. Football admiration has become a way of life, a subculture of recreation, and, sometimes, the ideology of life for a long time. 
The psychological basis of the behavior of sports fans, in contrast to criminal groups, is the need to show emotions that arose under the influence of football events. A gradual increase in emotional arousal leads to manifestations of aggression that cannot be controlled. In this case, the mechanisms are due to the essence of crowd psychology work.

Among the most typical manifestations of illegal behavior are brutal beatings of fans of the opposite team, hooliganism in stadiums, and after the competition - group acts of vandalism.

Hooliganism as a type of crime committed by football hooligans is one of the most common criminal offenses against public order. It violates public peace, norms of public morality, despises the results of human labor, encroaches on the physical and moral integrity of citizens, harms the health of victims and their property. More serious crimes are often committed based on hooliganism.

Today, the "fan movement" has become an integral part of football life. This phenomenon can be treated in different ways: to love or hate, to support or despise, but not to notice the fans every year becomes more difficult. There are incidents around the world involving football matches, affecting spectators, football clubs and teams, individual players, referees, and coaches. This results in mass riots, group disturbances, acts of vandalism, and other acts committed by football fans before, during, and after football matches. Analysis of this problem shows that some fans come to the stadiums specifically to cause riots, to exert psychological pressure on the course of the match, to provoke clashes between the opposing sides of the fans, or to direct their aggression at law enforcement officers (Golovchenko, 2004).

Before the COVID-19 pandemic, the growing number of football fans regularly attended both home and away matches of their favorite club, the national football team, and considered it a "matter of honor" to arrange fights with fans of the rival team, representatives of law enforcement agencies or to commit other illegal (criminal) encroachments, for the sake of expression of emotional excitement, own beliefs, etc.

Today, quarantine and matches without fans have removed the stands from football, but this does not mean that the environment of fans has decreased, especially those who belong to the "football hooligans". Online cheering (in bars, pubs, houses, apartments, parks, streets) is a reality of 2020-2021, which, unfortunately, is also not free from committing criminal offenses, including hooliganism.

Moreover, the issue of sanctions, or liability in sport, is not given enough attention by the legal environment to be considered as having an institutional framework for legal regulation (Bolokan et al., 2021). 
516 Viktor Boiarov, Mikhail Larkin, Oleh Kyrychenko, Sergey Penkov y Oleh Kruhlov

In this regard, I would like to dwell on the analysis of certain features of the investigation of crimes committed by football fans.

The object of research is the peculiarities of the investigation of hooliganism committed by football fans. The subject of the study is the features of hooliganism committed by football fans, the specific characteristics of the investigation of crimes committed by football fans.

\section{Methodology of the study}

During the writing of the article, such scientific methods were used as observation, analysis, synthesis, comparison, generalization, extrapolation, modeling, and information approach.

The observation method provides a general description of such a phenomenon as football hooliganism, an overview of its current state, the state of investigation of violations that occur during football matches, and in connection with the very fact of commitment to a particular football club.

Additionally, an investigation of trends in football hooliganism, highlighting the positive experience of foreign countries in the prevention of football hooliganism, found that criminal fan groups have now departed from traditional actions (hooliganism) and become criminal groups of extremist nature, having a certain ideological role. These actions are the result of using such a method as analysis.

Accompanying the method of analysis, the method of synthesis is applied, which is to combine the individual aspects of the study into a single whole. In particular, based on the use of types of groups of football fans, their role in shaping the system of prevention and investigation of crimes committed by football fans was highlighted. It should be noted that the use of such types of synthesis as direct and reverse at different stages of the study acquainted with the general features of the object under study and to understand its essence.

Further, the method of comparison was used to highlight the characteristics of certain groups of football fans, which in turn allowed to development of guidelines for improving the legal regulation of relations arising during the investigation of crimes committed by football fans.

Besides, extrapolation method, which consists of spreading the conclusions about one part of the object under study to another part as a result of observation. Thus, the actions of the investigator in conducting a pre-trial investigation of crimes committed by football fans, with the investigation of hooliganism as such, were interrelated. 
The method of generalization helped to recognize the main proposals for maintaining public order during football matches, to identify the feasibility of expanding existing methods of combating violations by football fans.

The application of the historical method made it possible to consider the object of research from the point of view of the peculiarities of development, which significantly enriches scientific research, testifies to the reliability of its results and conclusions, and confirms scientific objectivity.

A relatively new general scientific method is the information approach, according to which the study of any object or phenomenon reveals the most characteristic aspects of data. Thus, among a large number of scientific papers on the characteristics of football fans, the information was used that corresponds to the stated topic and is of practical value for the investigation of crimes committed by football fans.

The method of modeling was expediently utilized in the formulation of methods of counteracting and preventing crimes committed by football fans. Thus, modeling the proposed proposals, it is considered useful to use them in practice, having previously analyzed the theoretical aspects of such crime and international experience.

\section{Analysis of recent research}

During the writing of the article, international legal acts, works of domestic and foreign scholars were analyzed.

Among the international documents relevant in the context of this study is the European Convention on Spectator Violence and Misconduct during Sports Events and, in particular, Football Matches of August 19, 1985 (Council of Europe, 1985), and the Law of Ukraine "On Ratification of the European Convention on Spectator Violence and Misconduct". during sports events, and in particular football matches" No. 2791-III of November 15, 2001.

The BBC News (Parkinson,2016) also drew attention to the problem of the spread of crimes committed by football fans. According to BBC News methods of preventive nature in the field of public order during football matches are proposed. In particular, the position on the ban on the sale of alcohol on the day and before the match is relevant.

International experience in combating violations of the law by relatively new actors, such as football fans, draws attention, in particular, in the works of such scholars as Tkachenko (2015) and Borodavko (2011). Thus, these scholars have studied the European experience in combating crimes committed by football hooligans. On the example of Great Britain, Germany, 
and Italy, it can be stated, that the creation of specialized police (detectives), video surveillance of football fans during matches, and studying the database of potential violators, etc. is considered quite an effective action by the state.

The following scientists were engaged in the theoretical basis of studying the peculiarities of the behavior of football fans: Aristarkhova (2016), Granik (2014), Ille (1999), Trofimov (2015), Vayle (2012), Meitin (2003), Larkin (2018, 2019abc), Golovchenko (2004) and Rudik (2019).

In their works, the beginning of the formation of groups of football fans and the character of their development is investigated (Ille (1999), Meitin (2003), and Vayle (2012)). Thus, with the emergence of such a sport as football in the XIX century, there were also its fans, who later began to be called football fans. In the scientific literature, more and more attention was paid to the division of fans into types, which allowed to formulate the specifics of their activities and to develop appropriate ways to combat illegal activities in this area (Rudik (2019).

Due to the spread of violations of the law by football fans, there were proposals to prevent them and punish the perpetrators. This topic was actively studied by such scientists as Boiarov (2017ab), Larkin (2018, 2019abc), Rudik (2019), and Masalitin (2019ab).

Primary, Boiarov (2017ab) considered some issues of tactics of interrogation of suspects (football fans). In particular, theoretical preparation for interrogation is essential for the investigator, as the subject of suspicion is characterized by specific behavioral characteristics, such as enjoyment of the game and its expression in the aggressive actions, various mental health disorders, etc.

Further, Larkin (2018, 2019abc) and Masalitin (2019ab) have contributed to the development of scientific thought on the structure of forensic characteristics of hooliganism committed by football fans, the personality of a football hooligan, the practical significance of studying this topic.

Also, Rudik (2019) directly investigated the prevention of crimes committed by football fans.

A promising area of research and applied research of our stated problems is the development of guidelines for the investigation of football hooliganism, in particular, the basic methodology. The tactics of conducting an inspection of the scene, interrogation, search, taking into account the latest trends in practice, are to be studied. The use of special knowledge in the investigation of football hooliganism is subject to detailed analysis. Also, many significant issues related to the legal features of this criminal offense, the criminal law qualification of the relevant actions remain unexplored. 
Given the wide range of issues related to the activities of football fans around the world, it is advisable to further explore the relationship of football club management with football fans, to create a theoretical basis for the legal regulation of liability of all legal entities involved in football matches, etc.

\section{Results and discussion}

\subsection{Football hooliganism: current status and trends}

Football fans appeared almost simultaneously with the emergence of football - in the XIX century in England, after which mass fights between fans of rival teams is a traditional phenomenon that accompanies football matches.

In the following years, typical manifestations of illegal behavior of football fans are fights with fans of the opposing team; hooliganism in stadiums and places where fans spend their leisure time; intentional infliction of bodily harm, resistance to law enforcement officers, vandalism, etc.

It should be noted that unlike members of traditional youth criminal groups, the behavior of football fans has a completely different psychological component. In the initial stage, it is associated with the need to obtain certain emotions (strong emotional feelings), and only later, as a result of radicalization and politicization, aggression is added to this need, as a result of which the behavior becomes uncontrollable. In particular, crimes may be committed based on racial, national, or religious hatred or discord.

At the same time, the motivation of football fans is, sometimes, seen as a kind of motive for committing a crime against the rights and legitimate interests of man and citizen - hatred (prejudice) or hostility towards members of a competing sports team or society (football fans). These crimes are especially dangerous because of their mass character (Aristarkhova, 2016).

The subculture of football fans can be seen as a youth subculture of teenagers who live a normal life and "return" to this subculture during matches. It is a subculture of leisure that sets a pattern for behavior only concerning a football match and / or relationships with other football fans. It has developed special standards of appearance and behavior (they are conditional and optional) (Granik, 2014).

Fan groups are formed mainly of teenagers, for whom being among the fans, including in the fan groups, is an attempt to enter adult life, to get rid of the lack of attention to themselves. It is this environment with the help of social practices mandatory for fans (marches, speeches, flash mobs, making 
banners, etc.), and common to a group of specific slang, symbols, and attributes is the socialization of adolescents who thus enter into adulthood.

In criminology, fans are divided into several groups (Rudik, 2019). The most active and aggressive are members of the fan movement, which is part of the so-called fighting wing. They are in a group of 20-30 and up to 100-200. These are football hooligans (who are already an integral part of the world's fan culture), who often claim the status of the elite of the fan movement, and therefore have to take part in many fights. To maintain their status, these groups are obliged to make a significant number of trips each year with the team to other settlements (cities), where the movement of local fans is hostile to them.

Other groups of fans include:

- "football fans", which are characterized by a pronounced subculture;

- "football fans", who enjoy the game;

- Ordinary spectators who consider watching football matches as a form of leisure.

The politicization of the football fans' movement in the 1960 s significantly changed the nature of social ties in the environment, turning them into a public organization, with the choice of an ideology (for example, for "ultras" (fan style, which appeared in Germany after 1990) - left, right or far-right views). To identify them as fans, they have a uniform, and since the mid-70's the concept of "fan" was replaced by the concept of "football fan". It should be emphasized, football fanaticism, designed to unload the fan emotionally, is often used for extremist purposes.

Former UEFA head Michel Platini once tried to assess the current situation in modern football, in particular, he stated that"... in the stadiums, there is a growing trend of nationalist and extremist sentiments..." (Sports. $\mathrm{ru}, 2015)$.

In recent years, there has been a significant transformation of the fan movement. Researchers of this phenomenon suggest considering it either as a social movement, or as a social group, or as carriers of a specific subculture, believing that the fan (youth) subculture is characterized by a tendency and willingness to violence, made them an ideal actor in the mechanism of unconstitutional change of power (Ille, 1999).

Consider this phenomenon also as an element of the extremist environment (Trofimov, 2015); as a kind of street gangs (Vayle, 2012), or as a "protest group", or a youth group (in which the business component is of great importance) (Kolomoets et al., 2017). 
Researchers of illegal activities of football fans note the presence in the environment of such negative trends as increasing the number of serious and especially serious crimes committed in conditions of increased organization and politicization of football fans from among young people who are "mass extremist" (Vayle, 2012) with the perception of race and nationalist ideology (Meitin, 2003); their business component is becoming increasingly important in the activities of fan groups, although such groups were created as protest groups (Kolomoets et al., 2017).

Recently, among some football hooligans, the stratagem movement has become widespread - voluntary abstinence from alcohol, cigarettes, drugs, casual sex, for the most consistent - vegetarianism (Negodchenko, 2010).

\subsection{Problems of football hooliganism investigation}

The presence of a sufficiently structured and self-organizing group (group) of football fans requires the investigator during the investigation to establish the features of the functioning, organization, financing of the structure and particular persons (including persons suspected of committing crimes), who are members of the group of football fans, and about their place, and role in the group.

The most powerful European football fan organizations have direct contact with the top management of their football clubs and, as has happened many times, have influenced the club's policy. It even happened that the ultras decided issues in favor or against some players and so on. In Italy, almost all major clubs consult with the leaders of their ultras on all issues that can cause some resonance in the stands. In addition, nearly all European ultras have some kind of commercial relationship with the club. The club helps financially or gives the ultras to earn on the same paraphernalia, tickets (Negodchenko, 2010). Therefore, quite often the leadership (management) of football clubs does not help to identify and punish hooligan fans from the fan environment.

If earlier the investigation was faced mainly with hooliganism of fan groups before, during, and after a football match; then an effective mechanism was created to combat this phenomenon - conditions were created to record the illegal actions of fans and identify the culprits among them, in particular, by installing the necessary number of outdoor surveillance cameras (under Article 3 of the European Convention on the part of spectators during sporting events and, in particular, football matches (adopted in August 1985) (Council of Europe, 1985), the state is obliged "..to ensure the involvement of sufficient resources to protect public order and combat outbreaks of violence and misconduct, both on the areas and stadiums directly adjacent to the stadiums, and on the paths used by the spectators..”. 
Viktor Boiarov, Mikhail Larkin, Oleh Kyrychenko, Sergey Penkov y Oleh Kruhlov
522 Features of the investigation of hooliganism committed by football fans

In other words, criminal fan groups have now moved away from traditional actions (hooliganism) and are turning into criminal groups of an extremist nature, having an ideological component in their activities. This raises many issues related to the restructuring of the fight against this phenomenon, and, hence, the need to use other means that will help law enforcement agencies to more effectively conducting public and covert investigative, investigative, and other procedural actions) to overcome the problems of preventing crimes committed by youth football groups in Ukraine.

Among the ways of committing illegal acts, it is possible to single out the following (Trofimov, 2015; Yakuba, 2015; Sundiev, 2012):

- visual (production of brochures, graffiti, etc. of an extremist nature);

- verbal (proclamation of "strings" that affect human dignity, for example, concerning race, skin color);

- special (prepared with the use of items that are allowed to carry to the sports arena and which have a narrow purpose, such as bananas), and;

- combat actions (active violence against opponents).

Special attention should be paid to the development of guidelines for the detection and investigation of hooliganism committed by football fans. In particular, the information basis of the investigation (Larkin, 2018).

In order to create a methodology for investigating crimes committed by football fans (basic methodology), it is necessary to move away from traditional methods used to investigate mass (group) hooliganism of young people. First of all, we must proceed from the fact that in modern realities, football fanfare is qualitatively changing and transforming. Thus, all crimes committed by football groups are divided into four groups: "pre-match" (committed before a football match); "stadium" (during a football match); "post-match" (after the football match), and initiative (not related in time to the football match, but basically have a "football" motivation), and this should affect the structure of the investigation methodology.

The tactics of the inspection of the scene, interrogation, taking into account the latest trends in practice (Boiarov et al., 2020; Larkin, 2019c; Larkin, 2019b, Masalitin, 2019b) are subject to study. The use of special knowledge in the investigation of football hooliganism is subject to detailed analysis (Larkin, 2019a; Boiarov, 2017a; Larkin et al., 2020).

The interrogation of an informal suspect is a theoretical training of the investigator, which includes a comprehensive study of the criminal case, which is to systematize the facts about the event, the suspect's identity, identify inconsistencies and gaps in the investigated materials. There may 
also be a need to consult a specialist who studies the activities of various youth informal organizations.

As for the tactics of interrogation, the tactics of interrogation can be based on the use of personal data of the suspect with the activation of his positive qualities (in particular, when the suspect is a minor); explaining to him the positive consequences of cooperation with the investigation, the available compromise procedures. To establish psychological contact, the investigator uses the help of psychologists, etc. (Boiarov, 2017b).

The place of the crime can be (Kononenko, 2006):

- stadiums (49\%);

- stands (sectors) of stadiums (44\%);

- sports complexes (5\%);

- educational institutions (schools, universities, vocational schools) (9\%);

- adjacent territories (streets, squares, squares near stadiums, sports complexes, schools) (27\%);

- venues for sports events (7\%), and;

- other places (1\%).

This classification makes it possible to focus law enforcement officers on the most probable places of hooliganism in connection with sports events.

To prevent the commission of crimes related to the activities of football fans, it is necessary to know the preconditions for their occurrence. Based on the study of the behavior of football fans, it is possible to identify the following situations that precede the commission of relevant crimes: the emergence of provocative situations (these include: mistakes of players, referees, actions of enemy fans, etc.); conditions, in which there are no reasons for conflict (in this case, fans provoke spectators, other fans, law enforcement officials to commit acts of violence; the reason for these actions may be the defeat of a favorite team) (Larkin, 2019c).

Given the awareness of the possible causes of illegal behavior of football fans, it is possible to find mechanisms to prevent it. For example, these could be:

- additional check of things that spectators can bring with them to the stadium. It is seen, that such an inspection can be carried out not only by the staff of the organizer of the matches but also by the police;

- placement of spectators depending on their commitment to a particular team. This proposal is reflected in Art. 4 (b) of the 
Viktor Boiarov, Mikhail Larkin, Oleh Kyrychenko, Sergey Penkov y Oleh Kruhlov
Features the investigation foolball fans

Convention on Spectator Violence and Misbehaviour at Sports Events and in particular at Football Matches (Council of Europe, 1985), which provides for the need to effectively separate groups of fans of rival teams and to place groups of fans arriving from other places in separate stands when they attend matches.

To regulate the behavior of football fans and, accordingly, public order during football matches, ideas were put forward to ban the sale of alcohol on match days and the day before. This approach has a rational basis, but in practice, does not eliminate the problem. Thus, this idea was first tested in 1990 during the World Cup. The introduction of a ban on the sale of alcohol has led to clashes between football fans and the police. We agree with Jeff Pearson, a professor of criminal law at the University of Manchester, that the ban on the sale of alcoholic beverages could provoke a violent reaction from fans and the search for alternative sources of drinking. Another positive aspect of such a ban may be the impossibility of using bottles as weapons (Parkinson, 2016).

Law enforcement agencies play a significant role in stopping football hooliganism. It is possible to distinguish the following methods of prevention of public order violations during football matches on the example of Great Britain and Germany (Tkachenko, 2015):

- creation of a separate police unit that specializes in law enforcement during football matches. It is advisable to authorize such units to conduct video surveillance of approaches to the stadium before the match; using the appropriate database to detect known hooligans. The very presence of such police officers in the environment of matches stimulates law-abiding behavior of fans;

- to avoid provocations, disputes, and mass riots, law enforcement agencies should detain violators of the order only during breaks or after football matches, and;

- theoretical training of police officers before football matches, in particular, on the methods of communication with football hooligans, the study of tactics to combat resistance from violators.

In addition, in Italy, to facilitate the identification of persons who violate public order during football matches, the sale of registered tickets has been introduced. Thus, you must provide proof of identity when purchasing tickets. Also, the responsibility of football clubs for the behavior of football fans in the form of fines was introduced. The amount of fines differs depending on the nature of the offense (Borodavko, 2011). 


\section{Conclusions}

Thus, based on the above, it is possible to conclude that the study of such a phenomenon as football fans, allowed us to find mechanisms for investigating crimes and preventing them.

The methods of prevention:

1. Sale of registered tickets and prediction of seating of spectators depending on commitment to playing teams.

2. Special training of law enforcement officers on the methods of communication with football hooligans.

3. Increasing the responsibility for committing crimes not only by fans, but also by the owners of football teams. And,

4. Prohibition of the sale of alcoholic beverages on the eve and on the day of a football match and strengthening the level of control over the presence of prohibited items that can be transferred to the stadium.

The methods of investigation:

1. Raising the level of special knowledge of people who investigate crimes by football fans.

2. Study of the specifics of the crime scene.

3. Isolation of typical traces of crime and mechanisms of their formation (footprints, hands, various biological substances - blood, human life results, instruments of crime, etc.). And,

4. Establishment of specialized police departments, which are empowered to investigate such crimes, giving them the right to cooperate with local governments in terms of video surveillance at the venues of matches, declassification of confidential information about the organizers of matches, their connections with football fans.

\section{Bibliographic References}

ARISTARKHOVA, Tetiana. 2016. "Motives for committing extremist crimes against the rights and legitimate interests of a person and a citizen in the system of their criminalistic characteristics" In: Izvestia of the Tula State University: Economic and legal sciences. Vol.4, No. 2, pp. 49-61. Available online. In: https://cyberleninka.ru/article/n/motivy-soversheniyaprestupleniy-ekstremistskoy-napravlennosti-protiv-prav-i-zakonnyh- 
526 Viktor Boiarov, Mikhail Larkin, Oleh Kyrychenko, Sergey Penkov y Oleh Kruhlov

Features of the investigation of hooliganism committed by football fans

interesov-cheloveka-i-grazhdanina-v-sisteme-ih. Consultation date: 13/01/2021.

BOIAROV, Viktor; LARKIN, Mikhail; DUDOROV, Olexandr; PYROZHKOVA, Yuliia; LEGKYKH, Kyrylo. 2020. "Interrogation of the Victims During the Investigation of Crimes Committed by Youth Extremist Groups" In: Amazonia Investiga. Vol. 9, No. 28, pp. 281-87. Available online. In: https://doi.org/10.34069/AI/2020.28.04.31. Consultation date: 13/01/2021.

BOIAROV, Viktor. 2017a. "The use of special knowledge during the investigation of criminal proceedings on criminally punishable manifestations of extremism" In: Bulletin of Zaporizhia National University: Legal sciences. Vol. 2, pp. 141-147. Available online. In: http://nbuv.gov.ua/ UJRN/Vznu_Jur_2017_2_19. Consultation date: 12/12/2020.

BOIAROV, Viktor. 2017b. "Features of interrogation of suspects in criminal proceedings on extremist activities" In: Entrepreneurship, economy and law. No. 5, pp. 251-254.

BOLOKAN, Inna; SAMOYLENKO, Georgiy; TKALYCH, Maxym; PANCHENKO, Bogdan; DMYTRIV, Volodymyr. 2021. In: Sanctions in Sport: "The Relationship Between Legal and Local Regulation" Retos. Vol. 42, pp. 662-672.

BORODAVKO, Dmytrii. 2011. "International experience in preventing violations of public order during football matches" In: Customs business. Vol. 5, No. 77, pp. 112-125.

COUNCIL OF EUROPE. 1985. European Convention on Spectator Violence and Misbehaviour at Sports Events and in particular at Football Matches. Available online. In: https://www.coe.int/en/web/conventions/fulllist/-/conventions/treaty/120. Consultation date: 13/01/2021.

GOLOVCHENKO, Vitalii. 2004. "Peculiarities of formation of legal culture of youth" In: Law of Ukraine. Vol. 10, pp. 120-123

GRANIK, Volodymyr. 2014. "Football fans as one of the elements of the extremist environment" In: Scientific portal of the Ministry of Internal Affairs of Russia. Vol. 1, pp. 92-96.

ILLE, Andrii. 1999. "Football fanaticism in Russia: fan movement and subculture of football fans. Youth movements and subcultures of St. Petersburg (sociological and anthropological analysis)" In: Norma. St. Petersburg. Available online. In: http://subculture.narod.ru/texts/book2/ille.htm. Consultation date: 13/01/2021. 
KHARYTONOV, Evgen; KHARYTONOVA, Olena; KOSTRUBA, Anatolii; TKALYCH, Maxym; TOLMACHEVSKA, Yuliia. 2021. "To the Peculiarities of Legal and Non-Legal Regulation of Social Relations in the Field of Sport” In: Retos. Vol. 41, pp. 131-137.

KOLOMOETS, Tetiana; LIUTIKOV, Pavel; LARKIN, Mikhail. 2017. "Informal youth associations as a business reality" In: Baltic Journal of Economic Studies. Vol. 3. No. 5, pp. 294-297.

KOLOMOIETS, Tetianal; TKALYCH, Maxym; MELNYK, Petro; PANCHENKO, Bogdan; TOLMACHEVSKA, Yuliia. 2021. "Combating Corruption in Sport: Legal Aspect” In: Retos. Vol. 41, pp. 746-755.

KONONENKO, Nataliia. 2006. Investigation of hooliganism committed during sports events (doctoral thesis). In: National Academy of Internal Affairs. Kyiv. Available online. In: https://dduvs.in.ua/wp-content/uploads/ files/Structure/science/rada/dissertations/9/2.pdf. Consultation date: $12 / 12 / 2020$.

LARKIN, Mikhail; DUDOROV, Olexandr; PYROZHKOVA, Yuliia; DUDOROVA, Kateryna; BIRYUKOVA, Alina. 2020. "Investigation of Crimes Committed By Members of Youth Informal Groups" In: Amazonia Investiga. Vol. 9, No. 29, pp. 282-87. Available online. https:// doi.org/10.34069/AI/2020.29.05.32. Consultation date: 12/12/2020.

LARKIN, Mykhail. 2018. "Criminalistic characteristic of hooliganism that committed by football fans" In: Bulletin of Zaporizhia National University: Legal sciences. Vol. 4, pp. 107-111.

LARKIN, Mykhail. 2019a. "Use of special knowledge in the investigation of crimes committed by members of informal youth groups (associations)" In: Bulletin of Zaporizhia National University: Legal sciences. Vol. 3-4, pp. 105-110.

LARKIN,Mykhail.2019b. “Features of theinterrogation of thesuspected member youth informal group (association) during the pre-trial investigation" In: Bulletin of Zaporizhia National University: Legal sciences. Vol. 2, pp. 758o. Available online. In: http://www.law.journalsofznu.zp.ua/archive/ visnik-2-2019/10.pdf. Consultation date: 12/12/2020.

LARKIN, Mykhail. 2019c. "Peculiarities of carrying out the crime scene examination in the investigation of crimes that committed by the youth informal groups (association)" In: Bulletin of Zaporizhia National University: Legal sciences. Vol. 1, pp. 103-107. Available online. http://www.law.journalsofznu.zp.ua/archive/visnik-1-2019/13.pdf. Consultation date: 12/12/2020. 
Viktor Boiarov, Mikhail Larkin, Oleh Kyrychenko, Sergey Penkov y Oleh Kruhlov

MASALITIN, Artem. 2019a. "Some features of forensic characterization of crimes committed by football fans" In: Bulletin of Zaporizhia National University: Legal sciences. Vol. 1, pp. 115-123.

MASALITIN, Artem. 2019b. Investigation of crimes committed by members of groups of football fans. Doctoral thesis. Academy of Advocacy of Ukraine. Kyiv, Ukraine.

MEITIN, Oleksandr. 2003. "The subculture of football fans and its place in the criminal subculture. Law and Judicial Practice" In: Krasnodar University of the Ministry of Internal Affairs of Russia. Vol. 4, pp. 19-26.

NEGODCHENKO, Oleksandr. 2010. Prevention of illegal behavior of football fans. In: State University of Internal Affairs Affairs. Dneprop. Dnepropetrovsk, Ukraine.

PARKINSON, Justin. 2016. Five ways to stop football hooliganism. In: BBC News Ukraine. Available online. In: https://www.bbc.com/ukrainian/ society/2016/o6/160618_five_ways_to_stop_hooliganism_it. Consultation date: 13/01/2021.

RUDIK, Mykhailo. 2019. Prevention of crimes committed by youth football groups in Ukraine. Osvita. Kherson, Ukraine.

SPORTS.RU. 2015. Michel Platini: "Nationalist and extremist sentiments are growing in the stadiums. It is necessary to create a sports police". Available online. In: http://www.sports.ru/football/1028278895.html. Consultation date: 12/12/2020.

SUNDIEV, Ivan. 2012. "Cognitive technologies: the dark side of progress” In: Scientific portal of the Ministry of Internal Affairs of Russia. No. 1, pp.7984.

TKACHENKO, Volodymyr. 2015. "European experience in counteracting offenses committed by football hooligans" In: Science and Law Enforcement. Vol. 2, No. 28, pp. 10-15.

TKALYCH, Maxym; DAVYDOVA, Iryna; TOLMACHEVSKA, Yuliia. 2020. "Current State and Prospects of Development of the Sports System of Ukraine: Legal Aspects (Estado actual y perspectivas de desarrollo del sistema deportivo de Ucrania: aspectos legales)" In: Retos. Vol. 38, pp. 385-389.

TROFIMOV, Dmytrii. 2015. "On the main ways football fans commit crimes and offenses of an extremist nature" In: Scientific portal of the Ministry of Internal Affairs of Russia. Vol. 3, pp. 105-109. 
LAW OF UKRAINE. 2001. Law No. 2791-III, On ratification of the European Convention on Spectator Violence and Misconduct during Sports Events, and in particular Football Matches. Available online. In: https://zakon. rada.gov.ua/laws/show/994_o03. Consultation date: 13/01/2021.

VAYLE, Serhii. 2012. "Street gangs and their role in the modern development of the problem of merging common and political crime" In: Scientific portal of the Ministry of Internal Affairs of Russia. Vol. 4, pp. 33-37.

YAKUBA, Albert. 2015. Criminalization of subcultures of football fans in the context of the development of Internet communication. Doctoral thesis. Krasnodar University of the Ministry of Internal Affairs of Russia. Krasnodar. Available online. In: http://www.dslib.net/soc-struktura/ kriminalizacija-subkultur-futbolnyh-fanatov-v-uslovijah-razvitijainternet.html. Consultation date: 12/12/2020. 
Vol. 39 N $^{\circ} 69$

Esta revista fue editada en formato digital y publicada en julio de 2021, por el Fondo Editorial Serbiluz, Universidad del Zulia. Maracaibo-Venezuela 